work and the statistical interpretation have been undertaken by Mrs C A Norbury (Birmingham research unit) and Dr K W Cross (department of social medicine, Birmingham University), and we are especially grateful to them. We also thank the Office of Population Censuses and Surveys for the subsidiary analysis of the original material to provide the data for table II.

\section{References}

1 Logan WDP, Cushion AA. Morbidity statistics from general practice. Studies on medical and population subjects No 14. London: HMSO, 1958.

2 Office of Population Censuses and Surveys, Royal College of General Practitioners, and Department of Health and Social Security. Morbidity statistics from general practice. Second national study 1970-71. Studies on medical and population subjects No 26. London: HMSO, 1974. 3 Office of Population Censuses and Surveys, Royal College of General Practitioners, and Department of Health and Social Security. Morbidity statistics from general practice. Third national study 1981-82. London: HMSO, 1986. (Series MB5 No 1.)

4 Keating G, Mitchell EA, Jackson R, Beaglehole R, Rea $H$. Trends in sales of drugs for asthma in New Zealand, Australia, and the United Kingdom, 1975-81. Br Med f 1984;289:348-51.

5 Office of Population Censuses and Surveys. Hospital in-patient enquiry. London: HMSO, 1975 , 1978, 1981. (Series MB4.)

6 Ayres JG. Trends in asthma and hay fever in general practice in the United Kingdom 1976-83. Thorax 1986;41:111-6.

7 Cushley MJ, Tattersfield AE. Sudden death in asthma: discussion paper. $\mathcal{F} R$ Soc Med 1983;76:662-6.
8 Burney PGJ. Asthma mortality in England and Wales: evidence for a further increase, 1974-84. Lancet 1986;ii:323-6.

9 Ciba Foundation Study Group. Identification of asthma. Edinburgh and London: Churchill Livingstone, 1971 .

10 Gregg I. Epidemiological aspects. In: Clark TJH, Godfrey S, eds. Asthma. 2nd ed. London: Chapman and Hall, 1983.

11 Henry RL, Milner AD. Specialist approach to childhood asthma: does it exist? $\mathrm{Br}$ Med $\mathcal{J}$ 1983;287:260-1.

12 Marks RE, Hillier VF. General practitioners' views on asthma in childhood. Br Med $\mathcal{J}$ 1983;287:949-51.

13 Speight ANP, Lee DA, Hey EN. Underdiagnosis and undertreatment of asthma in childhood. BrMed F 1983;286:1253-6.

14 Lee DA, Winslow NR, Speight ANP, Hey EN. Prevalence and spectrum of asthma in childhood. BrMed F 1983;286:1256-8.

15 Cochran WG. Some methods for strengthening the common $\chi^{2}$ tests. Biometrics 1954;10:417-51. 16 Peckham C, Butler N. A national study of asthma in childhood. I Epidemiol Community Health 1978;32:79-85.

17 Kaplan BA, Mascie-Taylor CGN. Biosocial factors in the epidemiology of childhood asthma in a British national sample. F Epidemiol Community Health 1985;39:152-6.

18 Anderson HR, Bailey P, West S. Trends in the care of acute childhood asthma 1970-8: a regional study. BrMed F 1980;281:1191-4.

19 Khot A, Burn R, Evans N, Lenney C, Lenney W. Seasonal variation and time trends in childhood asthma in England and Wales 1975-81. BrMed $\mathcal{J}$ 1984;289:235-7.

20 Fleming DM, Crombie DL. The incidence of common infectious diseases: the weekly returns service of the Royal College of General Practitioners. Health Trends 1985;17:13-6.

21 Morrison-Smith J. "In my own time." Asthma. Br Med J 1979;ii:118-9.

(Accepted 25 November 1986)

\title{
Atrial fibrillation precipitated by acute hypovolaemia
}

\author{
J D EDWARDS, R G WILKINS
}

\section{Abstract}

Six patients with varying degrees of acute cardiorespiratory failure were seen. All patients deteriorated noticeably when rapid atrial fibrillation developed. In all patients intravenous digitalis failed to slow the ventricular response, and in three patients misguided attempts at electrical cardioversion failed. Haemodynamic monitoring showed a normal or low pulmonary artery occlusion pressure in all patients. Controlled expansion of plasma volume was associated with an immediate slowing of the heart rate in all patients, and the heart rate in all patients returned to sinus rhythm within $\mathbf{3 0}$ minutes of transfusion.

It is suggested that hypovolaemia in critically ill patients may contribute to the development of atrial fibrillation.

\section{Introduction}

Atrial fibrillation is a recognised complication of acute non-cardiac illness ${ }^{1}$ and in normovolaemic patients with underlying left ventricular dysfunction usually results in dangerous falls in cardiac output and perfusion pressure associated with a deterioration in gas exchange due to rises in pulmonary artery occlusion pressure. ${ }^{2}$ It has been suggested that hypovolaemia may precipitate atrial fibrillation in a critically ill patient and should be excluded, ${ }^{3}$ but this has never been documented adequately. Over two years we saw six patients who developed rapid atrial fibrillation in association with severe hypovolaemia which was shown by invasive monitoring.

\footnotetext{
Intensive Care Unit, Withington Hospital, West Didsbury, Manchester M20 8LR

J D EDWARDS, MRCP, consultant

R G WILKINS, FFARCS, consultant

Correspondence to: Dr Edwards.
}

\section{Patients and methods}

Case 1-A 56 year old man underwent emergency repair of a leaking aortic aneurysm. Postoperatively his central venous pressure was maintained at $10 \mathrm{~cm} \mathrm{H}_{2} \mathrm{O}$ from the sternal angle. He remained oliguric (urine output $10-15 \mathrm{ml} / \mathrm{h}$ ) and hypotensive (systolic blood pressure $100-105 \mathrm{~mm} \mathrm{Hg}$ ). Thirty six hours after surgery he suddenly became breathless, and his systolic blood pressure fell to $60 \mathrm{~mm} \mathrm{Hg}$. He was found to be suffering from rapid atrial fibrillation. Two attempts at cardioversion with direct current shocks of 150 and 400 joules failed. He subsequently developed adult respiratory distress syndrome, which necessitated mechanical ventilation for 10 days.

Case 2-A 48 year old man was admitted suffering from alcohol withdrawal, as evidenced by delirium tremens. On the day of admission he became progressively breathless. Fluid replacement seemed adequate (2.4 litres of crystalloid over seven hours), but he developed sudden circulatory collapse, worsening respiratory distress, and rapid atrial fibrillation. This did not respond to two attempts at cardioversion (200 and 400 joules, respectively). After resuscitation he was found to have bilateral bronchopneumonia.

Case 3-A 64 year old woman developed circulatory collapse and was found to be suffering from rapid atrial fibrillation 14 hours after a carotid endarterectomy. Three attempts at cardioversion (100, 200, and 400 joules) failed, and she developed progressive respiratory distress. After resuscitation she was found to have a staphylococcal septicaemia.

Case 4-Two days after surgery for a perforated duodenal ulcer a 62 year old man developed progressive hypotension (systolic blood pressure falling from 110 to $75 \mathrm{~mm} \mathrm{Hg}$ over six hours). Soon afterwards he became breathless, and the rhythm changed to atrial fibrillation. His respiratory distress was thought, on clinical and radiological grounds, to be due to left ventricular failure. He was subsequently shown to have septicaemia due to Escherichia coli and adult respiratory distress syndrome.

Case 5-A 46 year old woman was admitted with dyspnoea, which had developed over 24 hours. On examination she was found to be hypotensive and suffering from rapid atrial fibrillation. Chest radiography showed infiltration in the left lower lobe, which later became generalised. After resuscitation she was found to have pneumococcal pneumonia and septicaemia.

Case 6-A 64 year old man became hypotensive and breathless after a viral type illness that had lasted for $\mathbf{4 8}$ hours. On admission he was hypotensive and in extreme respiratory distress. He was suffering from rapid atrial fibrillation and had bilateral crepitations. Though he was initially thought to be suffering from left ventricular failure, haemodynamic studies and 
Results in six patients before and after expansion of plasma volume

\begin{tabular}{|c|c|c|c|c|c|c|c|c|c|c|c|c|}
\hline \multirow{2}{*}{$\begin{array}{l}\text { Case } \\
\text { No }\end{array}$} & \multicolumn{2}{|c|}{$\begin{array}{l}\text { Heart rate } \\
\text { (beats/min) }\end{array}$} & \multicolumn{2}{|c|}{$\begin{array}{l}\text { Mean arterial blood pressure } \\
(\mathrm{mm} \mathrm{Hg})\end{array}$} & \multicolumn{2}{|c|}{$\begin{array}{l}\text { Pulmonary artery occlusion pressure } \\
\qquad(\mathrm{mm} \mathrm{Hg})\end{array}$} & \multicolumn{2}{|c|}{$\begin{array}{l}\text { Stroke volume index } \\
\left(\mathrm{ml} / \mathrm{m}^{2}\right)\end{array}$} & \multicolumn{2}{|c|}{$\begin{array}{l}\text { Left ventricular stroke work index } \\
\qquad\left(\mathrm{g} \mathrm{m} / \mathrm{m}^{2}\right)\end{array}$} & \multirow{2}{*}{$\begin{array}{c}\begin{array}{c}\text { Fluid } \\
\text { volume } \\
\text { (litres) }\end{array} \\
\text { (a) }\end{array}$} & \multirow{2}{*}{$\begin{array}{l}\text { Fluid } \\
\text { timef } \\
\text { (min) }\end{array}$} \\
\hline & Before & After & Before & After & Before & After & Before & After & Before & After & & \\
\hline 1 & 177 & 102 & 40 & 85 & 12 & 16 & 8 & 31 & 3 & 29 & $4 \cdot 10$ & 50 \\
\hline 2 & 155 & 90 & 55 & 70 & 1 & 2 & 8 & 30 & 6 & 24 & $4 \cdot 20$ & 65 \\
\hline 3 & 180 & 110 & 45 & 90 & 10 & 15 & 7 & 22 & 3 & 22 & 2.25 & 35 \\
\hline 4 & 147 & 95 & 50 & 75 & 6 & 11 & 12 & 39 & 7 & 34 & 4.80 & 75 \\
\hline 5 & 170 & 115 & 30 & 65 & 2 & 18 & 5 & 27 & 2 & 17 & 3.75 & 40 \\
\hline 6 & 150 & 120 & 65 & 80 & 5 & 14 & 11 & 23 & 9 & 21 & $4 \cdot 30$ & 70 \\
\hline
\end{tabular}

^Total volume of modified fluid gelatin infused.

†Time taken to achieve controlled plasma volume expansion.

radiography subsequently showed that he had bronchopneumonia. He too developed adult respiratory distress syndrome.

All patients were eventually admitted to the intensive care unit of this hospital. All except the patient in case 3 required mechanical ventilation, and they all continued to suffer from rapid atrial fibrillation after intravenous digitalis had been administered in the form of ouabain 250-500 $\mu \mathrm{g}$. After hypoxaemia had been corrected pulmonary artery flotation catheters were inserted for measurement of right atrial pressure, pulmonary artery occlusion pressure, and pulmonary artery pressure, and cardiac output was determined by a standard thermodilution technique. Cannulas were inserted into the femoral arteries to measure systemic arterial pressures. The derived variables in the table were calculated by standard formulas. Plasma volume was expanded rapidly with modified fluid gelatin to an optimal pulmonary artery occlusion pressure, above which there were no further falls in heart rate or increases in left ventricular stroke work index.

\section{Results}

The results are shown in the table. Between $2 \cdot 25$ and $4 \cdot 9$ litres of fluid was needed (mean 3.91 litres). All patients developed slowing of the ventricular rate towards normal during transfusion, and the heart rate in all patients reverted to sinus rhythm within 30 minutes of plasma volume expansion. One patient (case 3) was discharged from the intensive care unit 12 hours after admission; the others remained in the unit for two to 12 days. The patients in cases 4 and 5 died. All the others made a good recovery.

\section{Discussion}

The deleterious effects of the sudden onset of atrial fibrillation in critically ill patients have been reviewed and include a rapid ventricular rate and loss of atrial transport. ${ }^{4}$ All the patients described above became much worse when the atrial fibrillation developed, but their response to fluids showed that the atrial fibrillation was a complication of an underlying illness rather than the primary cause of their acute deterioration. All patients had noticeable hypovolaemia, which had not been suspected but was. discovered when pulmonary artery occlusion pressures were found to be low or normal. A poor absolute correlation between measured circulating blood volume and pulmonary artery occlusion pressure $\vec{\circ}$ has been shown. ${ }^{5}$ The explanation almost certainly lies in the varying states of left ventricular compliance in critically ill patients. ${ }_{\sigma}$ Thus even when pulmonary artery occlusion pressure is not veryo low (as in cases 1 and 3) a trial of plasma volume expansion is. advisable. When filling pressure was normal it did not increase rapidly with transfusion. The usual response to onset of atrial fibrillation in critically ill patients whose circulating blood volume has been well maintained is for the pulmonary artery occlusion $N$ pressure to rise quickly to very high levels, and this, combined with $0_{0}^{N}$ falls in cardiac output, may worsen gas exchange and delivery of ${ }^{f}$ oxygen to tissues. ${ }^{2}$ Unmonitored plasma volume expansion in such? patients is therefore not recommended.

The reversion to sinus rhythm after transfusion suggests that hypovolaemia, in addition to the underlying condition, played ac major part in the precipitation of atrial fibrillation. We suggest thate haemodynamic monitoring is important in the management of hypotensive patients with uncontrollable atrial fibrillation.

\section{References}

1 Ledingham IMcA, McArdle CS. Prospective study of the treatment of septic shock. Lance

1978;i:1194-7.
2 Edwards JD, Kishen R. Significance and management of intractable supraventricular arrhythmias in critically ill patients. Crit Care Med 1986;14:280-2.

3 Vincent JL. Update in intensive care and emergency medicine. Berlin: Springer-Verlag, 1986. 3 Vincent JL. Update in intensive care and emergency medicine. Berlin: Springer-Verlag, 1986 .
1986;58:151-68.

5 Shippy CR, Appel PL, Shoemaker WC. Reliability of clinical monitoring to assess blood volume in critically ill patients. Crit Care Med 1984;12:107-12.

6 Calvin JE, Driedger AA, Sibbald WJ. The hemodynamic effect of rapid fluid infusion in critically ill patients. Surgery 1981;90:61-76.

(Accepted 25 November 1986)

\section{SHORT REPORTS}

\section{Penetration of pyrazinamide into the cerebrospinal fluid in tuberculous meningitis}

Although meningitis is a fairly uncommon form of tuberculosis, its consequences are particularly important as delays in diagnosis and in starting effective treatment can result in serious neurological consequences or even death. Because of the lack of controlled clinical trials evidence for the potential contribution of drugs to the treatment of tuberculous meningitis depends primarily on their efficacy in pulmonary tuberculosis and estimates of their penetration into the cerebrospinal fluid. Pyrazinamide has a key sterilising role in short course chemotherapy for pulmonary tuberculosis ${ }^{1}$ but has rarely been used for treating tuberculous meningitis. Before this investigation its penetration into the cerebrospinal fluid had been studied in only two patients. ${ }^{23}$
Patients, methods, and results

We studied 28 Chinese patients with suspected tuberculous meningitis; the were aged $18-71$ and weighed $28-80 \mathrm{~kg}$. The diagnosis was confirmed ito 25 patients on the basis of clinical symptoms and cerebrospinal fluid evidence. AE presentation consciousness was undisturbed in four patients and disturbed in 16, while five patients were comatose or delirious. In addition to daily treatment with pyrazinamide, isoniazid, and rifampicin most patients also received steroids and either ethambutol or streptomycin.

Lumbar punctures were performed only when required clinically to establish the diagnosis and to monitor therapeutic progress. In the first part of the्ष्ठ investigation 50 samples of cerebrospinal fluid and blood were obtained abou作 two hours after administration of the drugs. In the second part, 42 pairs of samples of cerebrospinal fluid and blood obtained concomitantly were collectec $b$ two, five, or eight hours after dosage, the timing on each occasion being by random allocation. Cerebrospinal fluid and serum pyrazinamide concentrations were determined colorimetrically with alkaline nitroprusside after extraction int butanol-toluene and thence into dilute sulphuric acid. ${ }^{4}$ Thirty three pairs of samples of cerebrospinal fluid and blood were obtained from patients during the 